DOI: $10.14451 / 2.125 .29$

\title{
ПРОБЛЕМЫ КВАЛИФИКАЦИИ ПРЕСТУПЛЕНИЙ ПРОТИВ СОБСТВЕННОСТИ
}

\author{
(c) 2018 Сальник Владимир Александрович
}

слушатель факультета подготовки сотрудников для оперативных подразделений полиции Московского университета МВД России имени В.Я. Кикотя

E-mail: abramovuv54@mail.ru

В статье показано, что не все обманные пути совершения мошенничества вписываются в описание модели поведения и не интегрируется в уголовно-правовую систему Российской Федерации с ее доктриной состава преступления. Автор пытается сформулировать содержательные и объемные дефиниции «обман» и «злоупотребление доверием», которые, будучи законодательно закрепленными, помогут снять все актуальные проблемы правоприменительной практики.

Ключевые слова: субъекты имущественных прав, квалификации преступлений, хищения как форма кражи, мошенничество с использованием электронных средств платежа, обман и злоупотребление доверием, киберпреступления.

Научная категория собственность определяется как исторически сложившаяся определённая социальная форма присвоения материальных благ, в первую очередь, средств производства. Желание присваивать, а также непосредственно обладать всегда было характерно человеку от истоков развития природы. Поэтому было бы вполне логичным утверждать, что с самых древних времен правонарушения и прежде всего преступления, касающиеся собственности, составляли значительную часть всех преступных действий, которые совершались человеком.

В современных условиях, при возрастании роли материальных ценностей в жизни людей, ситуация мало изменилась. Кроме того, актуальность проблемы преступлений против собственности, как правило, становится все более острой и злободневной, поскольку их количество неуклонно и неизменно растет [4, с.10].

Стоит отметить, что формы собственности, непосредственно признанные Конституцией Российской Федерации и Гражданским кодексом Российской Федерации и существующие в настоящее время в Российской Федерации, являются частной, муниципальной и государственной собственностью. В соответствии с указанными субъектами имущественных прав могут быть Российская Федерация, субъекты Российской Федерации, а также муниципалитеты, граждане и, соответственно, юридические лица. Владелец вещи - это, как правило, субъект, которому непосредственно принадлежат все полномочия владельца. Лицо, владеющее вещью без права собственности на нее, является «другим владельцем» в смысле главы 21 Уголовного кодекса Российской Федерации [7, с.48].

Квалификации преступлений в теоретическом плане представляет собой общую совокупность научных идей и взглядов, а также различных мнений, концепций, касающихся норм уголовно-правовой оценки общественно опасных деяний, и определения соответствия социально опасного деяния составу или, как правило, элементам преступлений. Установление уголовной ответственности и, как следствие, привлечение к ответственности за каждое преступление, непосредственно совершенное в соответствии с определенной статьей (части статьи) Уголовного кодекса призвано реализовать актуальный принцип неотвратимости наказания за каждое преступление, в полной мере обязательно учитывать характер и степень общественной опасности совершения преступления, но и не должно, как правило, приводить к какому-либо необоснованному приписыванию совокупности преступлений, также повторному учету одних и тех же обстоятельств, а также нарушению принципа законности и справедливости.

Стоит отметить, что существует несколько видов разделения преступлений против имущественных групп. В УК РФ все виды преступлений против собственности могут быть систематизированы нижеуказанным образом:

Преступления в личных интересах, непосредственно связанные с незаконным извлечением имущественной выгоды:

- кража чужого имущества: кража (ст. 158 УК РФ); мошенничество (статья 159); незаконное присвоение или растрата (ст. 160 УК РФ); грабеж (ст. 161 УК РФ); разбой (ст. 162 УК РФ); 
кража предметов особой ценности (ст. 164 УК РФ) [1].

- преступление, связанное с кражей: вымогательство (ст. 163 УК РФ).

- иные корыстные преступления: причинение имущественного ущерба путем обмана или злоупотребления доверием (статья 165 Уголовного кодекса Российской Федерации); незаконное присвоение автомобиля или иного транспортного средства без цели хищения (ст. 166 УК РФ).

Преступления, которые непосредственно относятся к собственности, как правило, не связанные с извлечением имущественных выгод: умышленное уничтожение или повреждение имущества (статья 167 Уголовного кодекса Российской Федерации); уничтожение или повреждение имущества по неосторожности (ст. 168 УК РФ).

Основополагающее место непосредственно отводится хищениям. Хищения классифицируются по форме. Форма кражи определяется способом ее совершения. Итак, воровство, мошенничество, грабеж и т.д.- это форма воровства. В свою очередь, воровство в любой форме классифицируются по различным основаниям в зависимости от наличия или, как правило, отсутствия квалификационных признаков. Среди форм воровства, непосредственно, которые можно принять во внимание смежное с ними вымогательство, можно выделить две подгруппы:

1) насильственные формы (грабеж, а также вымогательство и грабеж в сочетании с насилием);

2) ненасильственные формы (кража, незаконное присвоение, растрата, мошенничество, грабеж без насилия).

Необходимо отметить, что в главе 21 Уголовного кодекса Российской Федерации выделяется именно статья о краже, которая традиционно понимается как наиболее характерная «типичная» форма кражи. После статьи о краже непосредственно следуют правила об иных ненасильственных формах кражи, а потом, как правило, о насильственных. На окончательном месте в ряду правил о растрате расположена статья 164, которая отмечается не формой (методом) хищения, а особым предметом посягательства.

Мошенничество занимает особенное и определенное место среди преступлений против собственности, потому что это преступление часто отделяет тонкую грань от гражданско-правовых отношений, а также, мошенничество отличается от иных преступлений против собственности особым способом его совершения - обманом или же, соответственно, злоупотреблением доверием [6, с.40].

Суть обмана непосредственно, как правило, заключается в намеренном предоставлении ложной информации, которая не соответствует действительности, либо в молчании о достоверных фактах, либо в определенных преднамеренных действиях, которые направлены на общее введение в заблуждение владельца собственности или другого лица. Злоупотребление доверием при мошенничестве - это, как правило, использование доверия с владельцем имущества или другим лицом, уполномоченным, как правило, принимать решения о передаче этого имущества третьим лицам в корыстных целях.

Стоит отметить, что национальный законодатель, непосредственно выделяя слово «мошенничество» как юридический термин, определяющего преступление, не внес в определение нормы, которая является основанием для уголовной ответственности за этот социально опасный акт, такие смысловые элементы, как «обман» и «злоупотребление доверием».

Таким образом, при совершении мошенничества злоупотребление доверием возможно, в свою очередь, связано с обманом, но обман в данном случае является, как правило, скорее не конкретным методом преступных действий, а их итоговым результатом по отношению к намерениям преступника.

Необходимо отметить, что злоупотребление доверием гораздо реже непосредственно действует как самостоятельный способ совершения преступления, чем обман, и часто сочетается с обманом, например, в сложных формах финансового мошенничества [3, с.99].

Отсюда, объективная сторона преступлений, которая предусмотрена ст. 159 и 165 Уголовного кодекса, выделяются два альтернативных способа совершения преступления: путем обмана или злоупотребления доверием. Более того, последний метод непосредственно является, как правило, независимым, но в процессе совершения преступления злоупотребление доверием возможно мошенническим. Учитывая тот факт, что злоупотребление доверием - это самостоятельный способом совершения преступления как части преступления, оно не является фа- 
культативным, а обязательным признаком, то есть необходимым условием для привлечения к уголовной ответственности [8, с.100].

23 апреля Президент России Владимир Путин подписал Федеральный закон № 111-Ф3 о внесении изменений в Уголовный кодекс РФ, предусматривающий усиление ответственности за хищение средств с банковского счета, а также электронных денежных средств. Часть 3 ст. 158 («Кража») и ч. 3 ст. 159.6 («Мошенничество в сфере компьютерной информации») были дополнены новым квалифицирующим признаком. Отныне кража с банковского счета, а равно электронных денежных средств независимо от размера по тяжести приравнивается к краже в крупном размере и карается штрафом в размере от 100 тыс. до 500 тыс. руб., принудительными работами на срок до 5 лет либо лишением свободы на срок до 6 лет (со штрафом до 80 тыс. руб.). Еще одно возможное наказание - ограничение свободы на срок до полутора лет. При этом крупный и особо крупный размеры ущерба снижены до 250 тыс. и 1 млн. руб. соответственно.

Стоит отметить, что наименование ст. 159.3 УК РФ «Мошенничество с использованием платежных карт» изменено на «Мошенничество с использованием электронных средств платежа». Теперь статья предусматривает наказание в виде лишения свободы на срок до 3 лет - также независимо от размера хищения. При этом сохранены альтернативные виды наказания: ограничение свободы на срок до 2 лет, штраф в размере до 120 тыс. руб., исправительные работы на срок до 1 года.

Поправки являются реакцией государства на активный рост количества преступлений, связанных с хищениями с банковских счетов и электронных денег посредством интернета. По разным оценкам, в 2015-2017 гг. объем таких хищений составил почти \$120 млн. Тенденция вполне объяснима [2].

Киберпреступления совершаются дистанционно, и злоумышленники чувствуют себя в безопасности. У них непосредственно создается иллюзия полной защищенности от уголовного преследования. К тому же мягкие, зачастую условные сроки наказания, которые предусматривались старыми редакциями рассматриваемых статей УК РФ, лишали их страха ответственности.

Таким образом, необходимо сделать вывод, что множественность обманных путей совершения мошенничества и полное отсутствие обоб- щающего их определения приводят непосредственно к выводу о том, что описание модели поведения преступника, как правило, как определённого конкретного случая не интегрируется в уголовно-правовую систему Российской Федерации с ее доктриной состава преступления [5, c.59].

Необходимо отметить также, что выявление новых мошеннических приемов на основе непосредственно позволяют сформулировать содержательную и объемную дефиниции «обман» и «злоупотребление доверием», которые, будучи законодательно закрепленными, очевидно снимут все актуальные проблемы правоприменительной практики.

Кроме того, необходимо выделить латентность преступления экономической направленности, которая является составной частью общей проблемы латентности преступности и соотносится с ней как часть и целая. В результате два данных феномена обладают как общими родовыми признаками, так и видовыми отличиями. Можно утверждать, что на латентную преступность экономической направленности возможно распространение таких свойств латентности, как деление ее на естественную или искусственную, или объективную и субъективную, разграничение незарегистрированной преступности на скрытую и скрываемую, а также на смешанную или пограничную. Необходимо отметить, что латентность экономической преступности в отличие от латентности так называемой преступности обще-уголовного характера, обладает своей спецификой, обусловленной механизмом совершения деяний, посягающих на сферу экономических отношений, особенностью наступления общественно опасных последствий от их совершения, а также причинно-следственных зависимостей между совершенным деянием и наступившими последствиями. Несмотря на то, что зарегистрированная, т.е. выявленная и учтенная, обще-уголовная преступность также далеко не адекватно отражает реальное состояние криминализации общества, ее официальные показатели значительно ближе к действительности, особенно касающиеся наиболее опасных ее проявлений - убийств, причинение тяжкого вреда здоровью, разбоев, похищений человека, террористических актов, квалифицированных видов хищений и другие.

Другое дело - преступления, совершаемые в сфере экономической деятельности и дея- 
ния, относящиеся к таковым в силу наличия так называемой компетенции подразделений правоохранительных органов, прежде всего должностные преступления коррупционной направленности.

В силу более сложного механизма совершения большинства экономических преступлений, специфики их составов, осуществление оперативно-розыскных мероприятий и проведение следственных действий по делам, указанной категории требует от сотрудников знания не только оперативно-розыскного, уголовного и уголовно-процессуального законодательства, но и основ гражданского, финансового, налогового, предпринимательского и других отраслей права $[9$, с.26].

Таким образом, научные выводы, связанные с рассмотрением проблем квалификации преступлений против собственности требуют дальнейшего совершенствования уголовно-правового законодательства.

\section{Библиографический список}

1. «Уголовный кодекс Российской Федерации» от 13.06.1996 N63-Ф3 (ред. от 23.04.2018, с изм. от 25.04.2018) // «Собрание законодательства РФ», 17.06.1996, N25, ст. 2954, «Российская газета», N113, 18.06.1996, N114, 19.06.1996, N115, 20.06.1996, N118, 25.06.1996.

2. Федеральный закон от 23.04.2018 N111-Ф3 «О внесении изменений в Уголовный кодекс Российской Федерации» источник публикации - Официальный интернет-портал правовой информации http://www.pravo. gov.ru, 23.04.2018, «Российская газета», N88, 25.04.2018, «Собрание законодательства РФ», 30.04.2018, N18, ст. 2581

3. Александров К.Б., Кузьмина И.И. Проблемы разграничения мошенничества от правонарушений смежного характера // Научно-техническое и экономическое сотрудничество стран АТР в ХХІ веке. Хабаровск, 2015. Т. 2. С. 92-102; Стерликов Ф.П. К вопросу собственности как юридической и экономической категории // Вопросы экономики и права. 2017. № 2. С. 12-17.

4. Бакрадзе А.А. Злоупотребление доверием как способ совершения мошенничества // Российский следователь. 2016. № 24. С. 10 .

5. Бугаев В.А. Обман и злоупотребление доверием как способ причинения имущественного ущерба // Ученые записки Крымского федерального университета имени В.И. Вернадского. Юридические науки. 2015. Т.1. № 4 (67). C.57-62.

6. Ермакова О.В. Преступления против собственности. Научно-практический комментарий. Барнаул, 2015. $96 \mathrm{c}$.

7. Кузнецов А.П. Мошенничество (ст.159 УК РФ): ретроспективное исследование, проблемы квалификации // Научный поиск. 2017. № 3.1. С. 47-53.

8. Шхагапсоев 3.Л. Проблемы квалификации преступлений против собственности, совершаемых путем обмана или злоупотребления доверием // Общество и право. Краснодар, 2015. № 3 (25). С. 97-102.

9. Гладких В.И. Законодательные аспекты детерминации латентности преступлений экономической направленности// Проблемы латентности преступлений экономической направленности: материалы межведомственного круглого стола. ВНИИ МВД России, (Москва, 25 октября 2013 г.) / Под ред. д-ра юрид. наук, доцента Э.А. Васильева. Москва. 2014. 216с. 